\title{
STUDENTS' RESPONSES ON USING WHATSAPP DURING ONLINE LEARNING
}

\author{
Yuni Amelia \\ English Tadris Program, Faculty of TarbiyahAnd Teacher Training \\ State Institute for Islamic Studies Palu \\ Email: yuniamelia@iainpalu.ac.id
}

\begin{abstract}
Recently, the use of mobile devices to communicate, learn, attain knowledge, and share information. Whatsapp as one of free downloaded device applications become the most popular platform, especially among university students. It is also regarded as one of teaching and learning media that could facilitate collaborative learning even though in this online classes due to Covid-19 pandemic.

Challenges in attracting students' attention and interest become higher during online learning, since lecturer could not directly interact and teach students. Students are required to fast adapt this new way. This research investigates students' response on using Whatsapp as a learning tool during the online English Classes at State Islamic Institute of Palu. To get the result, there were 62 students of English Study Program at Tarbiyah and Teaching Education Faculty given 17 items of questionnaire. The result shows the majority of the students have positive responses and enjoy using Whatsapp as a learning tool during online classes. Even they love using Whatsapp.
\end{abstract}

Key Words: Responses, Whatsapp, Online Learning 


\section{Introduction}

Nowadays, online learning becomes one of many essential and efficient ways to be concerned about (Michael et al., 2019) ${ }^{1}$. This learning way facilitates interaction between teachers / lecturers and students online without face to face. Most EFL teachers carry out online learning using Google classrooms, Google meetings, and Zoom ${ }^{2}$. During Covid-19 Pandemic, in rural areas in Indonesia, online learning increasingly chosen by the teachers and lecturers. The Covid-19 pandemic creates different activities of learning, which is from home. Teaching and learning process are carried out by lecturers and students from home, to prevent all people from the spread of the virus. This condition opens the eyes of lecturers that teaching and learning process can be done remotely through online media. The online learning process is a learning experience carried out by students using different devices such as laptops, cell-phones, etc., with the help of internet networks ${ }^{3}$.

The need for learning during the Covid-19 pandemic led the government to issue recommendations for students of all levels to learn from home using online media ${ }^{4}$. During this online learning process, it is necessary to use technology,

${ }^{1}$ C.A . Michael, R., Webster, C.A., Nilges, L., Brian, A., Johnson, R., Carson, R., And Egan, "An Online Course to Prepare Preservice Teachers to Promote Movement Integration," American Journal of Distance Education 33, no. 1 (2019): 59-70.

${ }^{2}$ A. R. Hurlbut, "Online vs. Traditional Learning in Teacher Education: A Comparison of Student Progress.," American Journal of Distance Education 32, no. 4 (2018): 248-266.

${ }^{3}$ S. Dhawan, "Online Learning: A Panacea in the Time of COVID-19 Crisis," Journal of Educational Technology Systems 4, no. 1 (2020): 5-22.

${ }^{4}$ A Purwanto, "Studi Eksplorasi Dampak

Pandemi COVID-19 Terhadap Proses Pembelajaran Online Di Sekolah Dasar.," EduPsyCouns Journal 2, no. 1 (2020): 1-12. such as laptops and cellphones. Currently, teachers and students can use a variety of online teaching and learningmedia application, one of them is Whatsapp. It can connect one billion people, and can be used for both devices, laptop and cellphones. It is quite popular compared to other applications. Many students nowadays use this application for the purpose of communication, and connection ${ }^{5}$.

Whatsapp is being widely used by lecturers and students in daily life including in teaching and learning process. This application does not spend a lot of internet quota. It also has faster and easier communication service to help users and especially students sharing their ideas in Whatsapp group, by both written and spoken via voice note. All students in one class, and their lecturer can create room for discussion in group. Whatsapp provides students various features to express thought and ideas, such as sharing pictures, videos, files, recording voice and video, and many more. Thus, those facts that whatsapp widely used and has many supporting features, brought the researcher to conduct this study which is aimed to analyze students' response on using Whatsapp during online learning. Researcher is encouraged to find out student responses using WhatsApp, in order to be one of the evaluation materials for online learning, so that in the future, online learning can be further maximized.

This study examined the background of the study, literature review, method used, result and conclusion. Specifically, the data were collected is students' response toward the use ofWhatsapp during online learning. Data was collected by questionnaire, and

${ }^{5}$ Izyani Mistar and Mohamed Amin Embi, "Students' Perception on the Use of Whatsapp As a Learning Tool in Esl Classroom," Journal of Education and Social Sciences 4 (2016): 96-104, http://jesoc.com/wp-content/uploads/2016/08/Edu76.pdf. 
analyzed, and presented descriptively. The researcher hope that this study will provide significance further information of Whatsappfor online learning and students response using it.

\section{Background of the Study}

The majority of undergraduates students of English Study Program of State Islamic Institute of Palu are Whatsapp users. They chose this application as the easiest platform in online learning since the first time studying from home is held, for almost all subjects. The researcher also teaches using Whatsapp as a medium of transferring materials, sharing information, ideas, pictures, voice and other things supporting learning process in Descriptive Writing subject. Students are able to easily access all given files and deliver their responses. The researcher then takes role as an evaluator who actively gives feedbacks, comments and questions. Seeing from the simplicity of accessing network and its cost, using Whatsapp as a medium is easier and cheaper than other platforms like Zoom meeting, Google Meeting, Youtube, etc. Thus, whatsapp is researched in this study.

\section{Literature Review}

\section{The Use of Whatsapp}

Whatsapp is one of the most popular text and voice messenger application. It was invented by Jan Koum and Brian Acton in 2009 that formerly invented Yahoo $^{6}$. It has been available on application store since 2010. It uses phone's cellular or Wi-Fi connection to facilitate messaging, voice and even video calling globally, in pair or in a group. WhatsApp also provides various features like sharing images, voice, videos, links,

\footnotetext{
${ }^{6}$ M. Albergotti, Reed., Macmillan., Douglas., Rusli., Evelyn, “Facebook’s \$19 Billion Deal Sets High Bar," The Wallstreet Journal (2014).
}

so students still have chances to interact with their friends, and lecturer, even in a distance. These Whatsapp's features and functions are in line with Vygotsky Constructivist Learning Theory, that developing students' social interaction to raise and share information ${ }^{7}$. The effectiveness online teaching and learning can be improved through social interaction using the application.

The use and operation of Whatsapp are available and quite easy for students and lecturers all ages and financial background. A smartphone that is supported by internet data or Wi-Fi, Whatsapp installed, a teaching and learning process can be carried out online. The majority usage of Whatsapp and its flexibilities are interesting to be further investigated. Thus, the aim of this research is studying the effectiveness of Whatsapp as a learning tool based on students' response. Many improvements and positive inputs would be reviewed.

\section{The Importance of Whatsapp as A Learning Platform}

Nowadays, students are exposed to various communication tools from smartphone application ${ }^{8}$. Undergraduates spend their time on social media sites $^{9}$. Whatsapp is one of the most popular smartphone's applications that works

${ }^{7}$ Izyani Misar Mohamad Amin, “STUDENTS' PERCEPTION ON THE USE OF WHATSAPP AS A LEARNING TOOL IN ESL CLASSROOM," Journal of Education and Social Sciences 4 (2016): 96-104.

${ }^{8}$ Piper Fogg, “"The 24-7 ProfessorWhat to Do When Home Is Just Another Word for the Offiece'" 54, no. 21 (2008).

${ }^{9}$ Nchindo Richardson Mbukusa, "Perceptions of Students' on the Use of WhatsApp in Teaching Methods of English as Second Language at the University of Namibia," Journal of Curriculum and Teaching 7, no. 2 (2018): 113-119. 
mainly on smartphone. Whatsapp can facilitate large number of students within fast and short period of time. Students can easily perform dialogue, discussions and communication effectively ${ }^{10}$. They can express their thoughts using various features like attaching pictures, sharing videos, links, recording voice and videos, and many more. All of those features support students to actively learn using the application.

This study explored the use of Whatsapp and undergraduates' response on this application, because they already used it to communicate and interact each other during these years, especially in pandemic covid-19. Moreover, many studies have concluded that Whatsapp has positive impacts on education for its effective information-sharing and ease of communications ${ }^{11}$.

Considering the fact that Whatsapp has many benefits to students, it also supports students' active learning involvement in its conversation and discussion. The learning process through Whatsapp, will be students centered. Interaction among students also shows academic lessons sharing ${ }^{12}$. Information and knowledge sharing among students are unconsciously promoted. The majority of students said that they highly satisfied using Whatsapp because it increases their English reading habit and gives positive

\footnotetext{
${ }^{10} \mathrm{M}$ Trentin, G . Repetto, "Using

Network and Mobile Technology to

Bridge Formal and Informal Learning,"

Elsevier (2013),

http://dx.doi.org/10.1533/9781780633626.

${ }^{11}$ Izyani Misar Mohamad Amin, "Students'

Perception on the Use Of Whatsapp as A Learning

Tool in Esl Classroom," Journal of Education and

Social Sciences 4 (2016): 96-104.

${ }^{12} \mathrm{R}$ Patient, "Using Mobile Devices to Leverage Student Access Tp CollaborativelyGenerated Resources: A Case of WhatsApp Instant Messaging, South Africa University." (n.d.), http://versys.uitm.edu.my/prisma/view/viewPDF.ph p?pid+48319. .
}

impact to their confidence in learning ${ }^{13}$. Whatsapp is considered helping and supporting students' English learning performance.

Many higher institutions and universities around the world use Whatsapp to have communication through its group discussion forum, information and knowledge sharing ${ }^{14}$. Whatsapp have risen Undergraduates' learning performance and motivation. It also helps and supports students' performance to be more enthusiastically involved in learning activities by using its various features.

\section{Problem Statement}

The researcher noted that students face new challenging during this covid-19 pandemic, doing online learning. Numerous problems may arise in learning process. This study therefore allowed the researcher to further understand how students react and respond learning online using Whatsapp.

\section{Objective of the Study}

The objective of this study is to identify students' response about the use of Whatsapp in learning English.

\section{Research Methodology}

This study used descriptive quantitative research approach, focused on provide description of the investigation based on

\footnotetext{
${ }^{13}$ Mar . Ana . Christine, "Improving Learners' Reading Skills Through Instant Short Messages: A Sample Study Using WhatsApp" (n.d.), http://versys.uitm.edu.my/prisma/view/viewPDF. php?pid+48319.

${ }^{14}$ C. Echeverria, A., Nussbaum, M., Calderon, J., Bravo, C.,, \& Infante, "Face-to-Face Collaborative Learning Supported by Mobile Phones. Interactive Learning Environment," 19, no. 4 (2011), http://eujournal.org/index.php/esj/article/viewFil e/3909/3700.
} 
students' perception. A survey was used to collect data from samples. The respondents were the students of English Department, $2^{\text {nd }}$ semester in Tarbiyah and Teacher Education Faculty in State Islamic Institute of Palu. There were 3 classes, the total of the respondents are 62 studentsThe respondents were chosen because the researcher taught the classes latest semester and they use Whatsapp for almost all subjects. Besides, the researcher's responsibility to evaluate the teaching and learning process for a semester using Whatsapp based on students' responses.

A questionnaire was distributed using google form in a whatsapp group for this research. It consisted of 17 items of statements. The students were required to choose one best answer among 5 scales, Strongly Agree $=5, \quad$ Agree $=4$, Undecided $=3, \quad$ Disagree $=2, \quad$ Strongly Disagree $=1$. The questionnaire was adapted from a similar research.

\section{Results}

The results shows and focused on the students response on using Whatsapp during online learning.

a. The Graphic of Students' Response on Using Whatsapp during Online Learning.

Since this research is descriptive quantitative, the researcher presents the result item by item in graphic.

Figure 1. Below depicts item 1. Learning using Whatsapp is an interesting activity
Learning using Whatsapp is an interesting activity

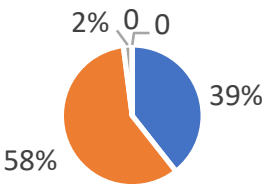

- Strongly Agree $\quad$ Agree

- Undecided $\quad$ Disagree

- Strongly Disagree

There were 58\% students agree, 39\% strongly agree that using Whatsapp is an interesting activity. Only $2 \%$ chose undecided, and no one chose the two other options.

Figure 2.

Learning Using Whatsapp is a Good Idea
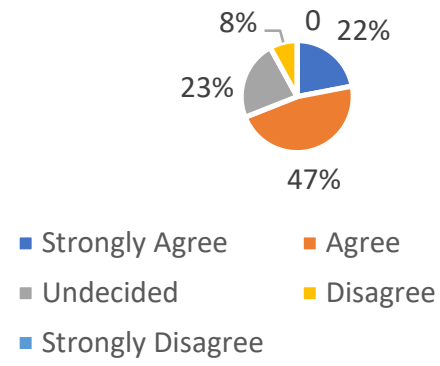

This second item quite similar to the first one. More than half students chose agree, $47 \%$, and strongly agree, $22 \%$, that learning using Whatsapp is a good idea. There were $23 \%$ chose undecided, $8 \%$ were disagree, and no one was strongly disagree. 
Figure 3.

\section{Learning Using Whatsapp is Easy}

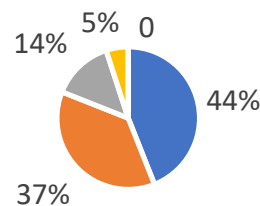

- Strongly Agree $\quad$ Agree

- Undecided Disagree

- Strongly Disagree

It shows that $44 \%$ students strongly thought that learning Whatsapp is easy, $37 \%$ were agree, $14 \%$ undecided, $5 \%$ were disagree, and no student thought the opposite.

Figure 4.

By Using Whatsapp, It is Faster to

Share Knowledge

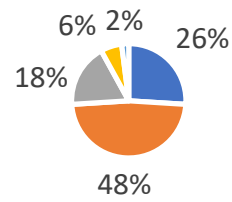

- Strongly Agree $\quad$ Agree

- Undecided $\quad$ Disagree

- Strongly Disagree

This item shows the utilization of using Whatsapp, faster to share knowledge. There were $48 \%$ students among all agree, $26 \%$ strongly agree, $18 \%$ undecided, $6 \%$ disagree and only $2 \%$ strongly disagree.

Figure 5.

By using Whatsapp, Information is Conveyed

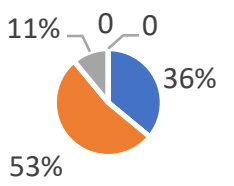

$$
\begin{aligned}
& \text { - Strongly Agree } \quad \text { - Agree } \\
& \text { - Undecided } \quad \text { Disagree } \\
& \text { - Strongly Disagree }
\end{aligned}
$$

By using Whatsapp, information is conveyed. There were $53 \%$ students chose agree, $36 \%$ agree and $11 \%$ students chose undecided.

Figure 6.

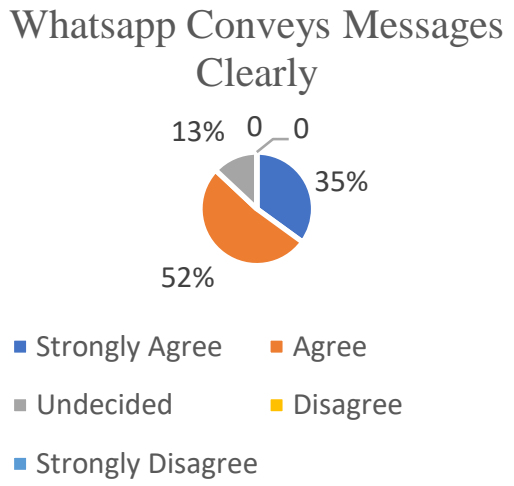

This graphic shows that 52\% students agree that Whatsapp conveys messages clearly, $35 \%$ strongly agree, $13 \%$ undecided, and no one disagree or strongly disagree.

Figure 7.

Whatsapp Helps Group Learning

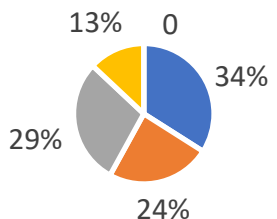

- Strongly Agree $\quad$ Agree
- Undecided $\quad$ Disagree
n Strongly Disagree

Little difference was showed in this graphic. There were 34\% strongly agree that Whatsapp helps group learning, directly followed by $29 \%$ students undecided of this statement, $24 \%$ agree, and $13 \%$ disagree.

Figure 8. 
Lecturers are Involved in

Learning Via Whatsapp

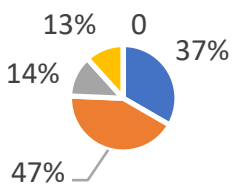

- Strongly Agree Agree

- Undecided $\quad$ Disagree

- Strongly Disagree

The eighth item of questionnaire mentioned about the involvement of lecturers in learning via Whatsapp. 37\% students strongly agree, followed by $47 \%$ agree, $14 \%$ undecided, and $13 \%$ disagree.

Figure 9.

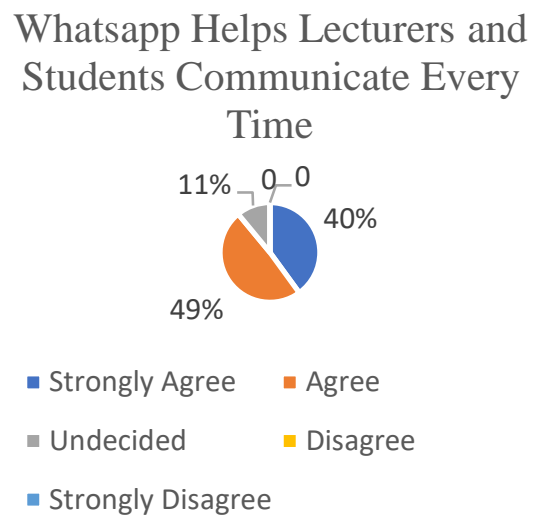

Whatsapp could facilitate lecturers and students communication. 49\% agree, $40 \%$ strongly agree, $11 \%$ undecided, and no student disagree and strongly disagree.

Figure 10.

Whatsapp is Useful in the Teaching and Learning Process

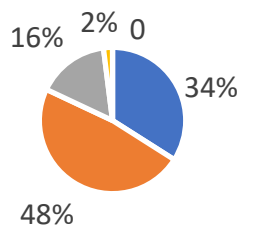

- Strongly Agree Agree

- Undecided Disagree

- Strongly Disagree
Whatsapp is useful in the teaching and learning process, there was $48 \%$ agree, $34 \%$ strongly agree, $16 \%$ undecided, $2 \%$ disagree and no student strongly disagree.

Figure 11.

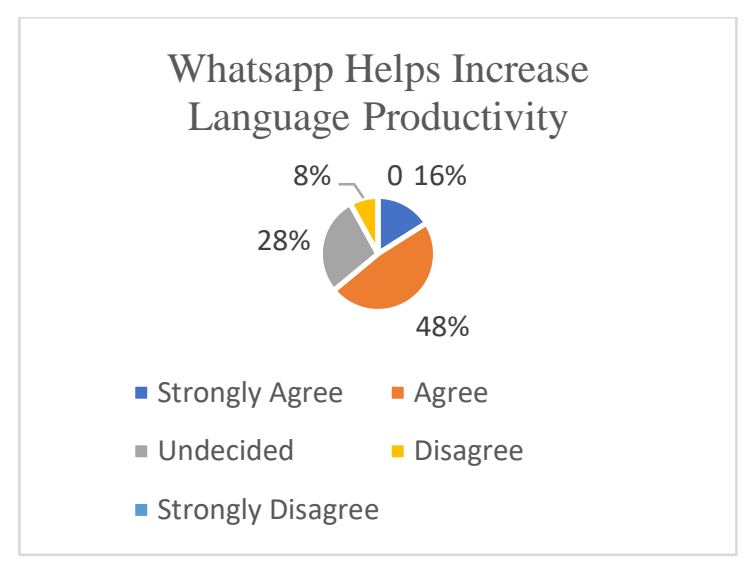

There was $48 \%$ students agree that Whatsapp helps increasing language productivity, $28 \%$ undecided, $16 \%$ strongly agree, and $8 \%$ disagree.

Figure 12.

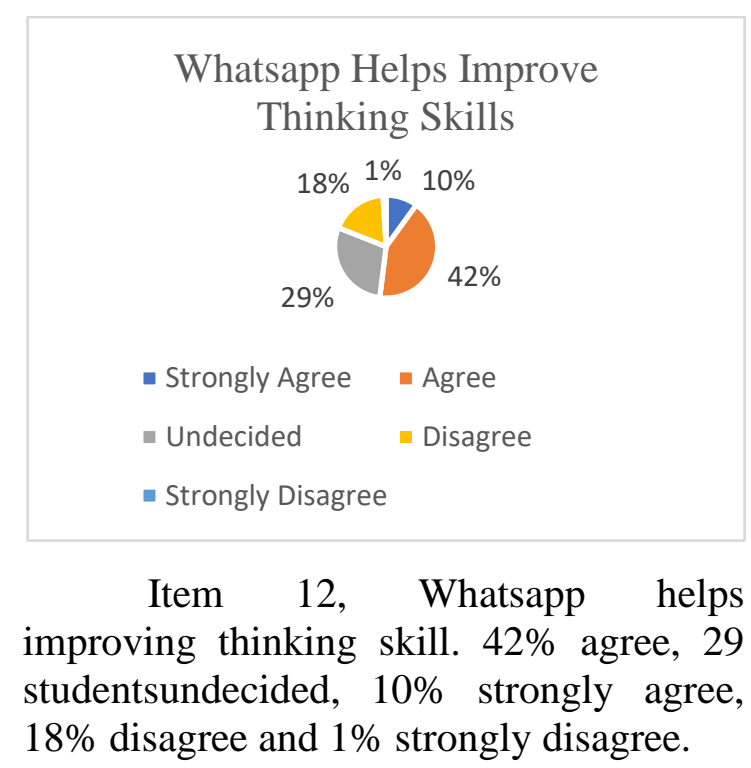


Figure 13.

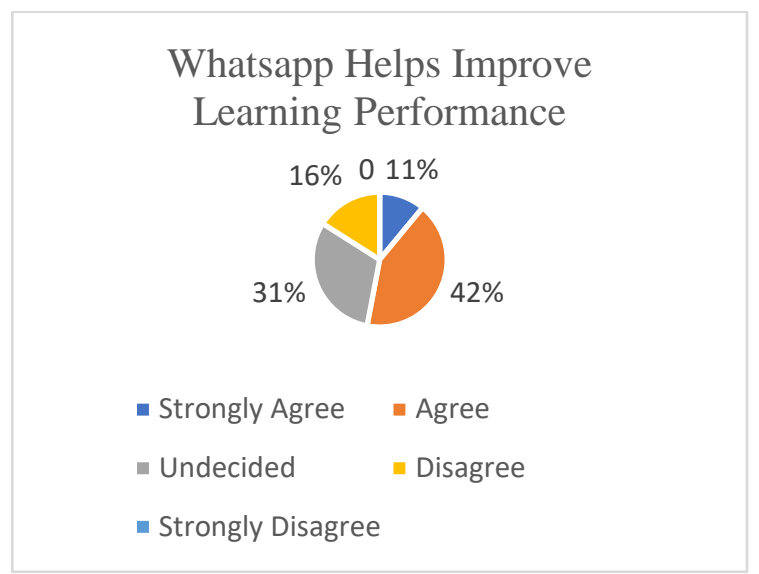

Learning performance could be improved by using Whatsapp in learning process. There was $42 \%$ agree, $31 \%$ undecided, $11 \%$ strongly agree, $16 \%$ disagree and no student was strongly disagree.

Figure 14.

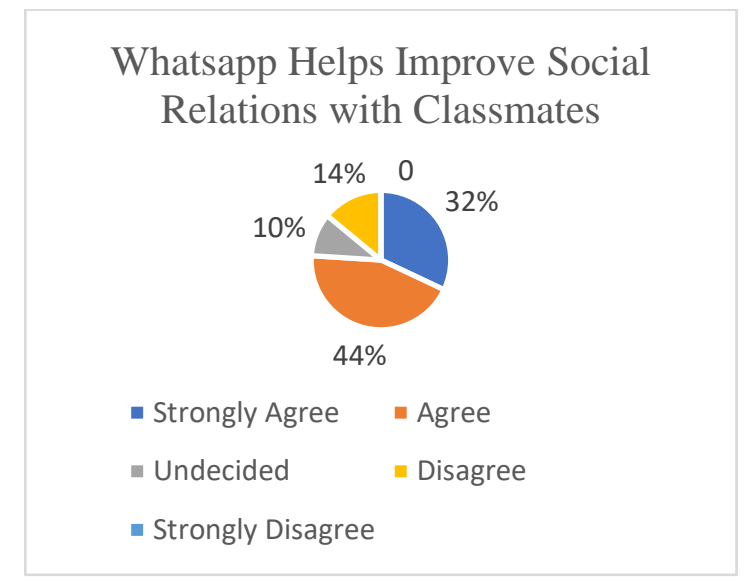

There was $44 \%$ students agree that Whatsapp helps improving social relations with classmates, $32 \%$ strongly agree, $10 \%$ undecided, $14 \%$ disagree.
Figure 15.

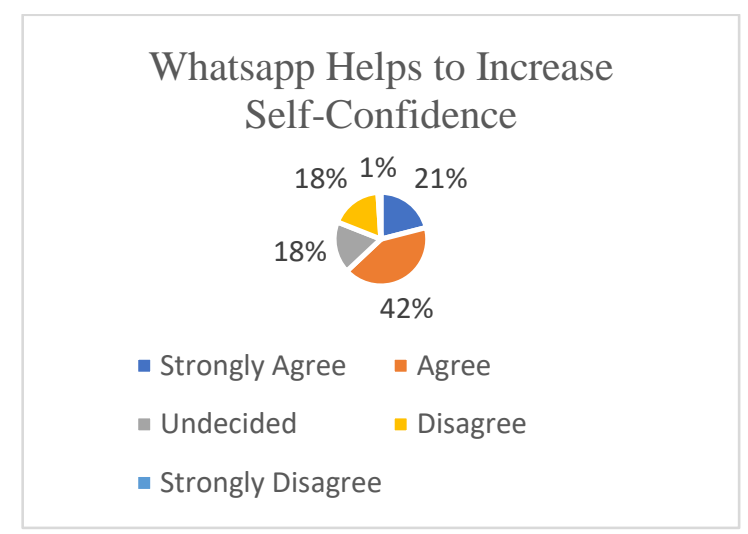

Self confidence could be increased by using Whatsapp. There was $42 \%$ agree, $21 \%$ students strongly agree, $18 \%$ undecided, $18 \%$ disagree and $1 \%$ strongly disagree.

Figure 16.

I agree if learning Using Whatsapp Continues

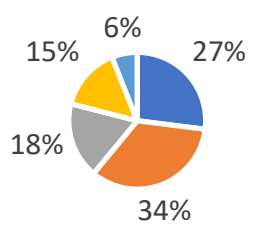

$$
\begin{aligned}
& \text { - Strongly Agree } \quad \text { Agree } \\
& \text { - Undecided }=\text { Disagree } \\
& \text { - Strongly Disagree }
\end{aligned}
$$

Seeing item 16, 34\% students agree that learning using Whatsapp could continue, $27 \%$ strongly agree, $18 \%$ undecided. But there was $15 \%$ disagree to continue learning using Whatsapp, and 6\% strongly disagree.

Figure 17.

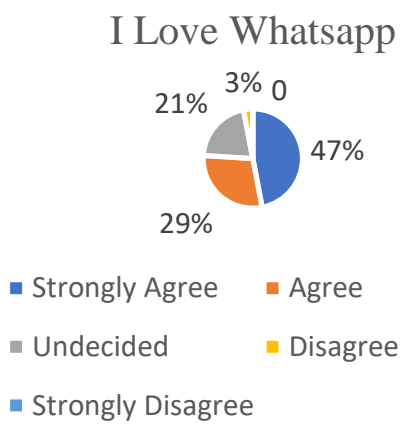


Majority of students love Whatsapp. 47\% strongly agree, $29 \%$ agree, $21 \%$ still undecided, $3 \%$ disagree.

Figure 18.

This last graphic shows overall data of the students' responses on using Whatsapp during online learning was $30 \%$ Strongly Agree, $44 \%$ agree, $18 \%$ undecided, $7 \%$ disagree and $1 \%$ strongly disagree.

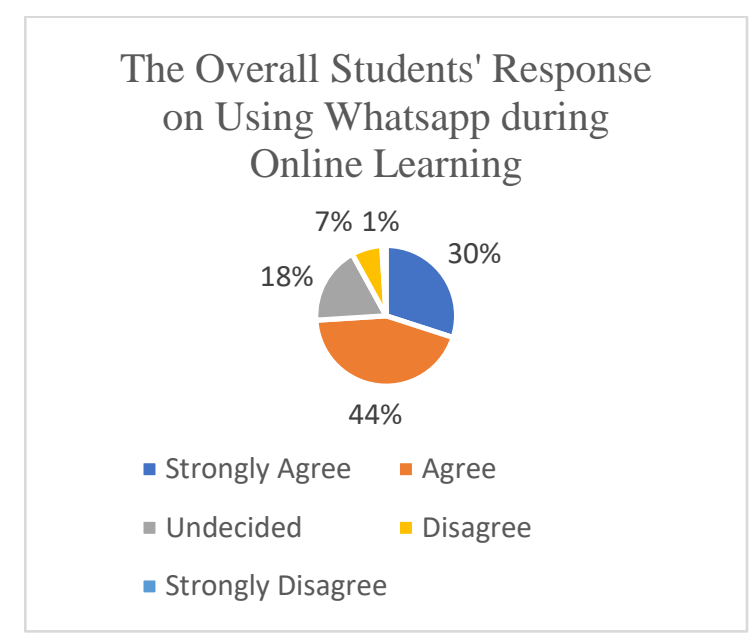

More than half of the students have positive responses on the use of Whatsapp during online teaching and learning process.

\section{Discussion}

Seeing all graphics as the results of the questionnaire of students responses using Whatsapp during online learning, most $2^{\text {nd }}$ semester students of English Study Program were having highly positive responses toward Whatsapp's application. Still, there were several students chose disagree for some items. There could be various reasons and factors behind their choices since this online learning has been passed for 2 semesters. The students may be bored learning only using Whatsapp, not having face to face meetings. It needs to be further researched to find deeper results.

\section{Conclusion}

Whatsapp can be a good option and resourceful teaching and learning media in this pandemic. Many students thinks that Whatsapp is still useful and helping them improve skill and knowledge and even love this application. Students still enjoy learning online using Whatsapp, as a learning tool. Lecturer may create more creative ways teaching using Whatsapp. 


\section{References}

Albergotti, Reed., Macmillan., Douglas., Rusli., Evelyn, M. "Facebook's \$19 Billion Deal Sets High Bar." The Wallstreet Journal (2014).

Christine, Mar . Ana . "Improving Learners' Reading Skills Through Instant Short Messages: A Sample Study Using WhatsApp" (n.d.). http://versys.uitm.edu.my/prisma/vie w/viewPDF.php?pid+48319.

Dhawan, S. "Online Learning: A Panacea in the Time of COVID-19 Crisis." Journal of Educational Technology Systems 4, no. 1 (2020): 5-22.

Echeverria, A., Nussbaum, M., Calderon, J., Bravo, C., \& Infante, C. "Face-toFace Collaborative Learning Supported by Mobile Phones. Interactive Learning Environment," 19, no. 4 (2011). http://eujournal.org/index.php/esj/arti cle/viewFile/3909/3700.

Fogg, Piper. “"The 24-7 Professor-What to Do When Home Is Just Another Word for the Offiece" 54, no. 21 (2008).

Hurlbut, A. R. "Online vs. Traditional Learning in Teacher Education: A Comparison of Student Progress." American Journal of Distance Education 32, no. 4 (2018): 248-266.

Michael, R., Webster, C.A., Nilges, L., Brian, A., Johnson, R., Carson, R., And Egan, C.A . "An Online Course to Prepare Preservice Teachers to Promote Movement Integration." American Journal of Distance Education 33, no. 1 (2019): 59-70.

Mistar, Izyani, and Mohamed Amin Embi. 'Students' Perception on the Use of Whatsapp As a Learning Tool in Esl Classroom." Journal of Education and Social Sciences 4 (2016): 96104. http://jesoc.com/wp-
content/uploads/2016/08/Edu-76.pdf.

Mohamad Amin, Izyani Misar. "Students' Perception on the Use Of Whatsapp as A Learning Tool in Esl Classroom." Journal of Education and Social Sciences 4 (2016): 96104.

—. 'STUDENTS' PERCEPTION ON THE USE OF WHATSAPP AS A LEARNING TOOL IN ESL CLASSROOM." Journal of Education and Social Sciences 4 (2016): 96-104.

Nchindo Richardson Mbukusa. 'Perceptions of Students' on the Use of WhatsApp in Teaching Methods of English as Second Language at the University of Namibia." Journal of Curriculum and Teaching 7, no. 2 (2018): 113-119.

Patient, R. "Using Mobile Devices to Leverage Student Access Tp Collaboratively-Generated Resources: A Case of WhatsApp Instant Messaging, South Africa University." (n.d.). http://versys.uitm.edu.my/prisma/vie w/viewPDF.php?pid+48319. .

Purwanto, A. "Studi Eksplorasi Dampak Pandemi COVID-19 Terhadap Proses Pembelajaran Online Di Sekolah Dasar." EduPsyCouns Journal 2, no. 1 (2020): 1-12.

Trentin, G . Repetto, M. "Using Network and Mobile Technology to Bridge Formal and Informal Learning." Elsevier (2013). http://dx.doi.org/10.1533/9781780633 626. 